\title{
FERTILIZATION OF BOVINE OOCYTES VITRIFIED PRE- AND POST IN VITRO MATURATION
}

\author{
Zakiyatul Faizah, Ninik Darsini, Aucky Hinting \\ Departemen Biologi Kedokteran, \\ Fakultas Kedokteran Universitas Airlangga
}

\begin{abstract}
ABSTRAK
Angka keberhasilan fertilisasi pasca simpan beku oosit masih sangat rendah, hal ini dikarenakan oosit memiliki sifat yang khas yaitu rasio volume dan permukaannya rendah menyebabkan terbatasnya penetrasi air dan krioprotektan menembus sel. Selain itu oosit matur memiliki benang spindle yang sangat rentan terhadap proses penurunan suhu. Simpan beku oosit sangat diperlukan terutama pada wanita yang perlu dilakukan penyelamatan kesuburan agar kelak oositnya dapat difertilisasi. Maturasi dilakukan dalam medium TC $100 \mu \mathrm{l}$ ditutup dengan mineral oil dalam cawan petri dengan diameter $36 \mathrm{~mm}$. Vitrifikasi diawali dengan pencucian oosit dalam medium PBS yang disuplementasi serum 20\% selama 1-2 menit, dilanjutkan dalam medium PBS + serum $20 \%+$ etilen glikol 10\% selama 10-14 menit. Oosit kemudian dipindahkan dalam medium vitrifikasi PBS + serum 20\% + sukrosa $0,5 \mathrm{M}+$ etilen glikol 15\% + PROH 15\% selama 25-30 detik. Thawing dilakukan dengan cara oosit direndam secara berturut dalam media: 1). PBS $+20 \%$ serum + sukrosa $0,5 M, 2)$. PBS $+20 \%$ serum + sukrosa 0,25M, dan 3). PBS + 20\% serum + sukrosa 0,1M. Inseminasi dilakukan dalam rosset, Jumlah fertilisasi diamati setelah 48 jam. Fertilisasi pada kelompok kontrol sebesar 42,97\%, sementara pada K1 dan K2 tidak ada fertilisasi sama sekali. Hasil analisis menunjukkan fertilisasi pada kelompok kontrol dan perlakuan berbeda secara signifikan pada p<0,05, pada kelompok perlakuan baik K1 maupun K2 tidak ada fertilisasi sama sekali. Simpulan penelitian ini adalah tidak ada perbedaan jumlah fertilisasi antara oosit sapi yang divitrifikasi pra dan pasca maturasi in vitro.
\end{abstract} (FMI 2016;52:104-107)

Kata kunci: vitrifikasi, fertilisasi in vitro

\begin{abstract}
The success rate of fertilization post save frozen oocytes is still very low, because the oocyte has distinctive features, namely the volume ratio and a lower surface to the limited penetration of water and cryoprotectants penetrate cells. Beside mature oocytes have a thread spindles are particularly vulnerable to the drop in temperature. Keep frozen oocytes is needed, especially in women who needed rescue fertility so their oosit can be fertilized. Maturation is done in TC $100 \mathrm{~mL}$ medium covered with mineral oil in a petri dish with a diameter of $36 \mathrm{~mm}$. Oocyte vitrification begins with washing in PBS supplemented medium serum 20\% for 1-2 minutes, followed by serum in the medium PBS $+20 \%+10 \%$ ethylene glycol for 10-14 minutes. Then oocyte vitrification medium is transported in PBS + serum $20 \%+$ sucrose $0.5 \mathrm{M}$ ethylene glycol $+15 \%+15 \%$ PROH for $25-30$ seconds. Thawing oocytes is done by successive immersed in the media: 1). PBS $+20 \%$ serum $+0.5 \mathrm{M}$ sucrose, 2). $P B S+20 \%$ serum $+0.25 \mathrm{M}$ sucrose, and 3$)$. PBS + $20 \%$ serum $+0.1 \mathrm{M}$ sucrose. Insemination is done in rosset, and the number of fertilization was observed after 48 hours. Fertilization in the control group amounted to $42.97 \%$, while the K1 and K2 there are no fertilization at all. The analysis showed that fertilization in the control and treatment groups significantly different at $p<0.05$ in both treatment groups K1 or K2 there are no fertilization at all. The conclusions of this study is there is no difference between the amount of fertilization of bovine oocytes were vitrified pre and post-maturation in vitro. (FMI 2016;52: 104-107)
\end{abstract}

Keywords: vitrified, In vitro fertilization

Correspondence: Zakiyatul Faizah, Departemen Biologi Kedokteran, Fakultas Kedokteran Universitas Airlangga, Jalan Prof dr Moestopo 47, Surabaya 60131.

\section{INTRODUCTION}

The success rate of fertilization post save frozen oocytes is still very low, this is because the oocyte has distinctive features, namely the volume ratio and a lower surface to the limited penetration of water and cryoprotectants penetrate cells (Cotichoi et al 2004). Additionally mature oocytes have a thread spindles are highly susceptible to temperature reduction process (Chen et al 2003). Keep frozen oocytes is needed, especially in women who needed rescue fertility so that their children oocytes can fertilized, it can occur in women with ovarian cancer who do not have a spouse. Keep frozen should be performed on oocytes immature to obtain more oocytes reserves, but until now the numbers post-fertilization oocytes vitrification immature still low.

Immature oocytes can be mature spontaneously when taken out of the follicle, it has been known for more 
than 70 years ago. In vitro maturation is a process of growth factor-mediated induction. Oocyte retrieval of dynamic environments prematurely, would disturb his capacitation in vivo. Deficiency that occurs during the maturation process will affect embryo development and implantation number, therefore the ability of the development of in vitro oocyte maturation results strongly influenced culture conditions. Deficiency during maturation has mostly to do with the cellular mechanisms of the programming on the core. Insufficiency in the maturation of the cytoplasm, are often still allows oocytes to mature but the inability of cellular mechanisms during maturation led to the failure of the embryonic development after fertilization (Carrell \& Peterson 2010). The success of oocyte maturation in addition to depending on the media and substances additives, also depends on the quality of the $\mathrm{CO}_{2}$ incubators are used. Good incubator will be able to distribute and regulate the concentration of $\mathrm{CO}_{2}$ permanently and evenly, and the temperature is not too much changed around $38^{\circ} \mathrm{C}$. Incubation in medium TCM 199 for 18 and 24 hours there was no significant difference in the numbers of maturation, respectively $71 \%$ and $76 \%$ (Prokofiev et al 1992).

The use of freeze-warmed oocytes can be compared to fresh oocytes in embryonic development (Kuwayama et al 2005). Chang et al (2011) mentions that the yarn spindles of oocytes can be maintained during the process of freezing and warming, even if exposed to extremely cold temperatures and undergo a transition phase 2 times. Vitrification on immature bovine oocytes showed better results when frozen with granulosa cells than without the granulosa cells (Kuwayama et al 2005). Procedure culture and store frozen oocytes is currently growing. Oocyte vitrification protect from the formation of ice crystals. Replacement of water with high concentrations of cryoprotectants protect cells when cooled and to prevent the formation of ice crystals, shock and osmotic shock fluid, so that the frozen oocytes can be matured for a further difertilisasi.Tujuan this study is the comparison between the amount of fertilization of bovine oocytes were vitrified pre and post-maturation in vitro.

\section{MATERIALS AND METHODS}

Total cleavage of $\mathrm{K} 0$ is $42.97 \% \pm 12.04$, significantly different from the group $\mathrm{K} 1$ and $\mathrm{K} 2$ are no cleavage at all at $\mathrm{p}<0.05$. Results with LSD Post Hoc test showed that the amount of cleavage on $\mathrm{K} 0$ with $\mathrm{K} 1$ and $\mathrm{K} 2$ shows significant differences $(\mathrm{p}<0.05)$, whereas in the group $\mathrm{K} 1$ to $\mathrm{K} 2$ there is a significant difference ( $\mathrm{p}$ $<0.05)$.

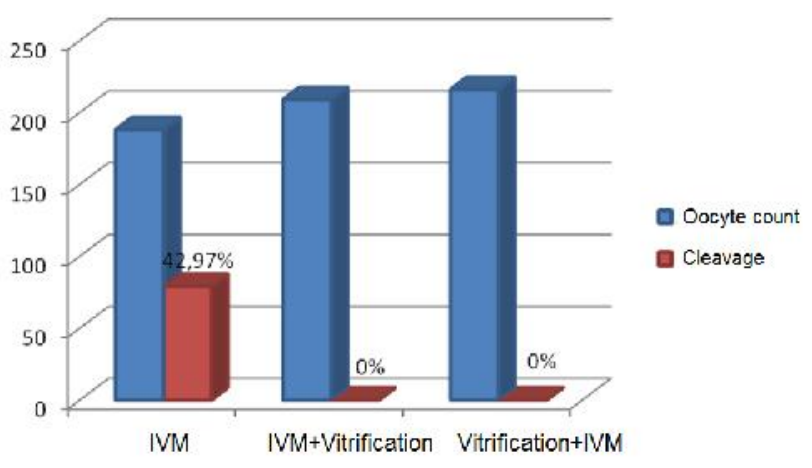

Figure 1. Mean cleavage

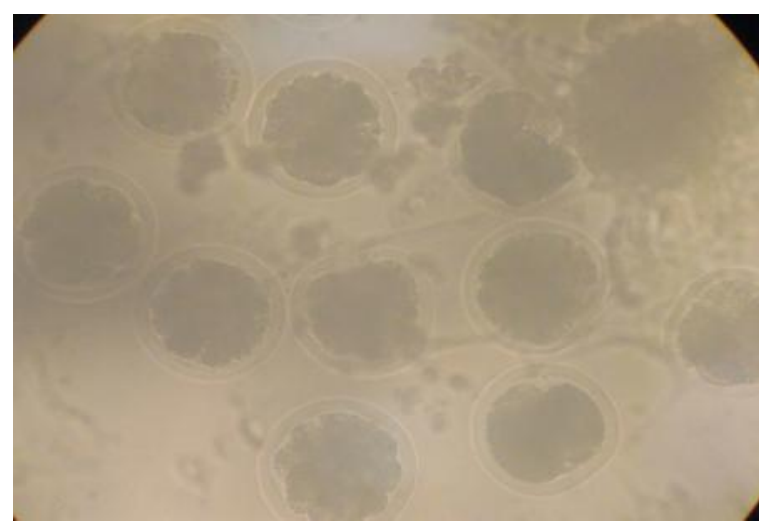

Fig. 2. Cleavage of embryos was observed after 48 hours, cleavage occurs from 2-8 cells

\section{DISCUSSION}

Fertilisation is the union of male and female gametes. IVF requires almost the same conditions that exist within the body. The environmental conditions need to be well prepared, medium, temperature, the incubator should be in prime condition for support of fertilization. Conditions are optimal oocyte and sperm also affect fertilization. Sperm will be able to fertilize an oocyte after undergoing a process of capacitation, the sperm to become more active and have more rapid motility to fertilize oocytes. Sperm also have to undergo the acrosome reaction by releasing enzymes that exist in his head to be able to penetrate the oocyte.

This study uses frozen cattle semen for fertilization, the sperm is processed with EBSS medium that has been added caffeine and heparin, preparation method used is a swim-up. Frozen sperm motility has lower after warmed $(70 \%-30 \%)$ but the morphology is similar to fresh semen (Parrish et al 1995). Warming and processing of sperm also plays an important role for fertilization. Medium EBSS a fertilization media containning the minerals calcium, potassium, magnesium 
and sodium chloride, $1 \%$ BSA and pyruvate as a nutritional ingredient spermatozoa during capacitation and fertilization of oocytes in vitro. Media EBSS also contain heparin and caffeine. Niwa et al (1988) reported that in mammals, the most suitable medium for the capacitation and fertilization is media containing mineral, is also equipped with heparin and caffeine.

This study showed no fertilization at all the treatment groups both $\mathrm{K} 1$ and $\mathrm{K} 2$ although the number maturation and normal morphology in both treatment groups is quite high, whereas in the control group there is fertilization of $42.97 \%$. Inability fertilization oocytes after vitrification process can be caused due to the ongoing apoptosis during cell culture. Men et al (2003) stated even though $92 \%$ of oocytes had normal morphology after vitrification, in the course of his culture the number of oocytes that showed increased expression of caspase 3 increased. Apoptosis also occurs in cumulus cells were frozen using DMSO and $\mathrm{PROH}$, the number of cumulus cells undergoing apoptosis ranged from $15-70 \%$ (Hu et al 2012), cumulus cell damage caused low ability of oocytes for fertilization. Factors cooling, cryoprotectants and osmotic shock to trigger apoptosis.

Cumulus cells play an important role in fertilization, the presence of cumulus cells can minimize the release of cortical granules that will prevent premature hardening zone. Vitrification results in the release cumulus cells that surround the zone although apparently still intact (VandeVoort et al 2007). Changes in ion $\mathrm{Ca}$ in the zona pellucida trigger the hardening zone, three cryoprotectants commonly used in vitrified ie $\mathrm{PROH}, \mathrm{EG}$ and DMSO generates change of calcium in the zona pellucida, EG provides increased very little, PROH effect a sustained increase (Larman et al 2007 ) and DMSO provides the greatest effect (Larman et al 2006). Tian et al (2007) reported vitrification using EG and DMSO resulted in a decrease in the number of sperm penetration of the oocyte, cortical granule distribution is uneven, the release of all cortical granule and improved digestion of the zona pellucida. Vitrification using PROH also lead to changes in the distribution and early release of cortical granules in oocytes mature and immature. Cortical granule which should neatly lined up on the edge of the oocyte is located deep within the cytoplasm (Gethler et al 2006).

A decrease in the release of cortical granules and increased penetration of sperm in the vitrification zone obtained by using calcium-free medium (Fujiwara et al 2010, Kohaya et al 2011). Changes to the zone will inhibit fertilization, Mavrides \& Morroll (2005) states the need to bypass the post-oocyte vitrification to occur by performing ICSI fertilization. Fusion occurs after the sperm penetrates the zona pellucida, the sperm will fuse with the cytoplasmic membrane, fertilization failure can be caused failure of sperm fusion with the cytoplasmic membrane despite already successfully passed through the zona pellucida. Cytoplasmic membrane susceptible to clotting, $\mathrm{CH}_{2}$ bond in the cytoplasmic membrane undergo changes during oocyte freezing. These changes occurred in the frozen oocytes in immature and mature phase (Ghetler et al 2005).

\section{CONCLUSION}

There is no difference between the fertilization of bovine oocytes vitrified pre and post-maturation in vitro. Further research is needed to see if there is damage to the oocyte cytoplasm and the zona pellucida examination to see if the failure of fertilization is due to the factor of hardening zone.

\section{REFERENCES}

Carrel TD and Peterson CM (2010). Reproductive Endocrinology and Infertility, New York, Springer, $p$ 635

Chang CC, Lin CJ, Sung LY, Kort HI, Tian XC, Nagy ZP (2011). Impact of phase transition on the mouse oocyte spindle during vitrification. Reproductive Biomedicine Online 22, 184-191

Chen SU, Lien YR, Chao KH, Ho HN, Yang YS, Lee TY (2003). Effects of cryopreservation on meiotic spindles of oocytes and its dynamics after thawing: clinical implications in oocyte freezing-a review article. Molecular and Cellular Endocrinology 202, 101-107

Coticchio G, Bonu MA, Borini A, Flamigni C (2004). Oocyte cryopreservation: a biological perspective. European Journal of Obstetrics \& Gynecology and Reproductive Biology 115, S2-S7

Fujiwara K, Seita Y, Inomata T, Junya ITO, Kashiwazaki N (2010). Ethylene glycol-supplemented calcium-free media improve zona penetration of vitrified rat oocytes by sperm cells. Journal of Reproduction and Development 56, 169-175

Ghetler Y, Yavin S, Shalgi R, Arav A (2005). The effect of chilling on membrane lipid phase transition in human oocytes and zygotes. Human Reproduction 20, 3385-3389

Ghetler Y, Skutelsky E, Nun IB, Dor LB, Amihai D, Shalgi R (2006). Human oocyte cryopreservation and the fate of cortical granules. Fertility and Sterility 86, 210-216

$\mathrm{Hu}$ W, Marchesi D, Qiao J, Feng HL (2012). Effect of slow freeze versus vitrification on the oocyte: an animal model. Fertility and Sterility 98, 752-760 
Kuwayama M, Vajta G, Kato O, Leiobo SP (2005). Highly efficient vitrification method for cryopreservation of human oocyte. Reproductive Biomedicine Online 11, 300-308

Kohaya N, Fujiwara K, Junya ITO, Kashiwazaki N (2011). High developmental rates of mouse oocytes cryopreserved by an optimized vitrification protocol: the effects of cryoprotectants, calcium and cumulus cells. Journal of Reproduction and Developmet 57, 675-680

Larman MG, Katz-Jaffe MG, Sheehan CB, Gardner DK (2007). 1,2-propanediol and the type of cryopreservation procedure adversely affect mouse oocyte physiology. Human Reproduction 22, 250-259

Larman MG, Sheehan CB, Gardner DK (2006). Calcium-free vitrification reduce cryoprotectantinduced zona pellucida hardening and increases fertilization rates in mouse oocytes. Reproduction 131, 53-61

Mavrides A and Morroll D (2005). Bypassing the effect of zona pellucida changes on embryo formation following cryopreservation of bovine oocytes. European Journal of Obstetric \& Gynecology and Reproductive Biology 118, 66-70

Men H, Monson RL, Parrish JJ, Rutledge JJ (2003). Degeneration of cryopreserved bovine oocytes via apoptosis during subsequent culture. Cryobiology 47, 73-81

Niwa K, Oghada O, Yuhara M (1988). Effects of caffeine in media for pretreatment of frozen-thawed sperm on in-vitro penetration of cattle oocytes. Proc 11 th Int Congr Anim Reprd Al 3, 346

Parrish JJ, Krogenaes A, Susko-Parrish JL (1995). Effect of bovine sperm separation by either swim-up or Percoll method on success of in vitro fertilization and early embryonic development. Theriogenology 44, 859-869

Prokofiev MI, Ernst LK, Suraeva NM, Lagutina IS, Udavlennikova NN, Kesyan AZ, Dolgohatskiy AI (1992). Bovine oocyte maturation, fertilization and further development in vitro and after transfer into recipients. Theriogenology 38, 461-469

Tian SJ, Yan CL, Yang HX, Zhou GB, Yang ZQ, Zhu SE (2007). Vitrification solution containing DMSO and EG can induce parthenogenetic activation of in vitro matured ovine oocytes and decrease sperm penetration. Animal Reproduction Science 101, 365 371

VandeVoort CA, Shirley CR, Hill DL, Leibo SP (2007). Effects of cryoprotectants and cryopreservation on germinal vesicle-stage cumulus-oocyte complexes of rhesus monkeys. Fertility and Sterility 90, 805-816 